\title{
THE KYIV PERIOD OF MIKHAIL MORDKIN'S CREATIVITY (1918-1919)
}

\author{
Uliana Danyliuk \\ Postgraduate Student, Kyiv National University of Culture and Arts, Ukraine \\ e-mail: ulana-7-dan@ukr.net, orcid.org/0000-0001-8479-1716
}

\section{Summary}

The purpose of the study is to identify the main directions of Mikhail Mordkin's creativity in Kyiv in 1918-1919. Chronological, comparative, typological and other methods are used in this work. The Kyiv period of M. Mordkin's creativity is associated with his pedagogical, performing and choreographic activities. His productions of the ballets Flowers of Granada, Giselle, La Fille mal gardée (The Wayward Daughter), as well as dance numbers and divertissements in opera and drama performances became meaningful to the artistic life of the city. M. Mordkin gained valuable experience of the director as a result of cooperation with Ukrainian creative intellectuals (L. Kurbas, M. Bonch-Tomashevsky, A. Petritsky, V. Verkhovinets). The stage production skills of Mordkin as the dancer served as an example for many Ukrainian artists. Mordkin as the teacher managed to significantly increase the size of the ballet troupe of the Kyiv Opera in a short time. It was made thanks students from his own studio, he expanded their professional capabilities through careful and systematic physical training. The research materials can serve as a basis for creating special courses on the history of choreography, can be used in subsequent theoretical studies devoted to the learning of Russian and Ukrainian ballet theaters or in the educational process in academic institutions of the corresponding profile.

Keywords: ballet, dance, choreography, Ukrainian ballet theater, choreographic art.

\section{DOI: https://doi.org/10.23856/4803}

\section{Introduction}

The history of the Ukrainian ballet theater of the first quarter of the XX century has many famous names of Russian dancers and choreographers, whose stage work significantly influenced the development of ballet art in Ukraine, such as Bronislava Nijinska (of Polish origin), Alexandre Kochetovsky, Leonid Zhukov, Maria Reizen, Kasyan Goleizovsky, Asaf Messerer, Rostislav Zakharov. An honorable place among the listed masters of the Russian ballet scene is also occupied by the creative individuality of Mikhail Mordkin, whose active performing and ballet-master's activities significantly strengthened the artistic processes in the Kyiv theater environment of the 1910-1920s.

It should be noted that the work of M. Mordkin in Ukraine has repeatedly become the subject of research by Russian and Ukrainian leading figures of art history. Among them are Elizaveta Surits (Surits, 2006) and Yurii Stanishevskyi (Stanishevskyi, 2002; Stanishevskyi, 2003). Based on the chronology of events presented by the named art critics, we managed to supplement the Kyiv period of M. Mordkin's creativity with new historical and art facts (the names of M. Mordkin's Kyiv students, the names of the divertissements he staged, details of pedagogical work with the actors of the Molody Teatr (Young Theater) by L. Kurbas). In particular, the main sources of these facts are the memoir literature of V. Vasylko (Vasylko, 1984), O. Stalinskyi (Stalinskyi, 1994) and materials from the theatrical periodicals of 1918-1919 (Muzykalnyj vestnik, 1919; Teatral, 1919; Visti, 1919). 
The purpose of our research is to identify the main directions of creativity of Mikhail Mordkin in Kyiv in 1918-1919. Chronological, comparative, typological and other methods are used in this work.

\section{The ballet life of Kyiv of the early XX century}

Despite the fact that by the early XX century Kyiv was a large industrial, economic and cultural center of the southwestern part of the empire, classical ballet as an integral theatrical phenomenon did not exist in its artistic life before the mid-1920s. In order to fully present the staging capabilities of the only one ballet troupe in the city of the Kyiv City Theater, we will illustrate several facts that characterize the state of ballet art in the city and the pace of its development in the early XX century.

Thus in 1908, thanks to the significant efforts of the choreographer S. Lenchevsky, the corps de ballet of the theater increased to nine pairs, which allowed the artists and the director to present to the Kyiv audience the expanded choreographic divertissement Primorsky Holiday for the first time. In 1909, choreographers S. Lenchevsky and M. Lange staged one act from Cesare Pugni's ballet Catarina ou la Fille du bandit. An important event in the work of the Kyiv ballet troupe was the premiere of one act from the ballet Robert and Bertram by G. Ostrembinger and the one-act performance Les Sylphides (Chopiniana) staged by choreographer K. Zalevsky in 1910. In the same year, the troupe was able to perform on its own the expanded act Walpurgis Night from the opera Faust by Charles Gounod, where the original technical equipment was first used for the so-called "flying ballet" (Stanishevskyi, 2002: 110).

The show of full-act ballet performances on the stage of the Kyiv Opera Theatre became possible only thanks to the tours of the artists of the Imperial Theaters from Moscow and St. Petersburg. One of the first such performances was a tour of a large group of dancers from the St. Petersburg Imperial Mariinsky Theater led by soloists O. Smirnova and N. Obukhov in 1911. Along with excerpts from famous ballets (Swan Lake by P. Tchaikovsky, Paquita by L. Minkus), the dancers presented full-scale performances on the Kyiv stage: Coppélia by L. Delibes, The Magic Flute by R. Drigo, La Fille mal gardée (The Wayward Daughter) by P. Hertel, La Halte de cavalerie by J. Armsheimer.

In the following year, 1912, a group from Petersburg headed by L. Egorova and S. Andriyanov arrived in Kyiv on tour, who showed the local residents Swan Lake and Sleeping Beauty by P. Tchaikovsky, The Little Humpbacked Horse by Cesare Pugni (Stanishevskyi, 2002: 110-111).

3. The first visits of M. Mordkin to Kyiv

The Moscow ballet premier Mikhail Mordkin began his regular visits to Kyiv in 1913 . According to the materials of E. Surits, the artist came with tours to Kyiv at least four times: April 16-21, 1913; April 9-15, 1914; in March 1915; April 11-20, 1916. The researcher suggests that the artist could be connected with the city on the Dnieper not only by close theatrical, but also personal ties (Surits, 2006: 90).

Little is known about the first two visits of M. Mordkin to Kyiv: he arrived with his partner A. Balashova to perform on the stage of the City Opera House.

In March 1915, the dancer arrived in Kyiv as a member of a group of artists from the Moscow Bolshoi Theater; they performed the show Flowers of Granada, music by M. Moshkovsky (scenography by P. Kuznetsov and V. Dyachkov, libretto by K. Goleizovsky), as well as divertissements: Norwegian Dances, Dance of the Gallic Warrior, Blind Happiness choreographed by M. Mordkin (as a performer distinguished himself as a first-rate mimic actor) (Surits, 2006: 91-92). 
In the theatrical season 1915-1916 M. Mordkin and A. Balashova together with a group of artists from the Moscow Bolshoi Theater showed the Kyiv citizens the ballets Giselle by Adolphe Adam and La Fille mal gardée (The Wayward Daughter) by P. Gertel (conductor P. Chimino).

According to E. Surits, the compositional interpretation of Mordkin's Giselle was, to some extent, borrowed from the production of A. Gorsky, premiered in 1907 (the artist performed the part of Albrecht in it) (Suric, 2006: 62). M. Mordkin's interest in A. Gorsky's edition was not accidental. The thing is, is that the main features of the ballet reform carried out by A. Gorsky at the turn of the XIX and XX centuries were quite confidently observed in Giselle. First of all, he brought out stage conventions from A. Adam's ballet, essentially synthesizing dance and pantomime; turned to historical primary sources and created the real national flavor on the stage; rethought and reproduced the consistent logic of the story progress; developed the effectiveness and strengthened the dynamics of separate parts; improved the compositional construction of corps de ballet scenes due to the asymmetric arrangement of artists on the stage, etc. (Poklad, 2017: 195).

Following the Giselle by A. Gorsky's, M. Mordkin also made the costumes more authentic (customized them for each individual artist), endowed not only the leading performers, but also the corps de ballet participants with their own line of behavior; developed new details for the image of the main character (Albrecht). According to E. Surits, M. Mordkin was the one who rethought the mise-en-scène of the beginning of the first act (inherent in many modern editions of Giselle), in which the Duke of Silesia made his way to the hut opposite Giselle's house to dress as peasant before meeting Giselle (Surits, 2006: 62).

In La Fille mal gardée (The Wayward Daughter) M. Mordkin turned to the work of A. Gorsky again. The Ukrainian researcher O. Bilash suggests that the production by A. Gorsky in 1903 on the stage of the Moscow Bolshoi Theater served as an example to follow (Bilash, 2019: 76).

It should be noted that M. Mordkin's performances in Kyiv not only aroused incredible admiration of his talent, but also significantly increased the interest of the Kyiv audience in ballet art. The novice Ukrainian artist Oleg Stalinskyi (later the soloist of the Kyiv State Academic Opera and Ballet Theater named after T. Shevchenko) was among the admirers of M. Mordkin's creativity. Oleg Stalinskyi wrote in his memoirs: "I have finally established myself in my dream [to dance], seeing a couple of years later the artist of Bolshoi Theater Mikhail Mordkin with his partner Balashova, who came on tour to Kyiv. First time I saw a dancing man, and how dancing! He was very successful and became the idol of the public. For the first time I got into the atmosphere of theatrical excitement, for the first time I came under the powerful influence of talent. I was conquered, in love, literally dreamed of Mordkin" (Stalinskyi, 1994: 338).

\section{Creation of a dance studio and production of ballets by M. Mordkin}

Mikhail Mordkin came to Kyiv again two years later. It should be noted that theatrical life in Kyiv has intensified as much as possible since the mid-1918. "Red banners were fluttering and cold and hunger reigned in Moscow and Petrograd, and Kyiv, which was at that time in the so-called "neutral zone", attracted with warmth and bread, relative prosperity and the still unknown possibilities of bourgeois democracy" (Chechel, 1993: 23). In the summer of 1918 the city was filled with scientists, Moscow and Petrograd celebrities, entrepreneurs, artists, painters. The actor, director and playwright Nikolai Evreinov successfully presented his theatrical evenings at the Art Theater of Miniatures, the actress Stanislava Vysotskaya studied 
in practice the possibilities of the human body and voice in the field of dramatic art according to the Stanislavsky system.

In addition to the creative intellectuals from Moscow and St. Petersburg, artists from provincial theaters, which were closed as a result of the socio-economic collapse, came to Kyiv for the purpose of job search. The increase of the artistic potential in the city contributed to the creation of the "Trade Union of Stage Figures" in March 1918, which was looking for an engagement for its members. More comfortable living conditions in Kyiv (compared to Moscow) got held up M. Mordkin in the city for more than one year. He arrived here in the summer of 1918, together with him came: his wife - Bronislava Pozhitskaya, stage partner Margarita Froman and her brother - dancer Max Froman. Almost immediately after arrival, the management of the Kyiv Opera (at the beginning of the 1918-1919 season it was renamed the K. Liebknecht Kyiv State Opera House) signed a contract with M. Mordkin and M. Froman to arrange weekly ballet performances.

Given the lack of ballet stuff in Kyiv, first thing Mordkin attempted to train qualified ballet dancers in his own dance studio, located in the spacious lobby of the Molody Teatr (Young Theater) (17 Proriznaya) - a drama troupe led by avant-garde director Les Kurbas.

M. Mordkin's lessons with the actors of Kurbas were one of the conditions upon which the premises were rented. Vasyl Vasylko, a member of the Molody Teatr (Young Theater), left memories of this unique stage practice. He wrote: "Fate brought us together with Mikhail Mikhailovich Mordkin in a very interesting way. He wanted to organize a ballet studio in Kyiv and was looking for premises for it. Once he came to us, examined the premises and offered to sublet the theater lobby at the time when we were not working, that is, from 8 to 10 in the morning and from 3 to 6 in the afternoon. We all knew Mordkin well from his tour in Kyiv with his former partner ballerina Balashova ... S.K. Bondarchuk conducted negotiations with M.M. Mordkin on behalf of our management. Although we needed money desperately, the interests of creativity were above. Bondarchuk replied to Mordkin that on condition that he personally practice plastic education with us, we would sublet our lobby to him. For such a master, the prospect of plastic education practice with 'ignoramus' is, of course, bondage, but he had no other choice, and he agreed. Thus our classes with Mordkin began three times a week. We were happy, but Mikhail Mikhailovich suffered incredibly with us, especially with those who were slow-paced. Sometimes he despaired. And yet the lessons continued in an atmosphere of complete devotion to the teacher" (Vasylko, 1984: 144).

By the early of April 1919 M. Mordkin formed a certain team of young dancers, whose efforts (with the participation of soloists Bronislava Pozhitskaya, Margarita Froman and Max Froman) was organized a choreographic evening on the stage of the Theater of the Ukrainian Soviet Republic named after V. Lenin (former Russian Drama Theater "Solovtsov"). The concert program included dance numbers: Dreams and Waltz by F. Chopin, The Torment of Love and The Joy of Love by F. Kreisler, Punchinelle by S. Rachmaninov, Dying Swan by C. SaintSaens, as well as the one-act ballet 2 nd Rhapsody by Franz Liszt. The orchestra was directed by the conductor M. Steiman (Teatral, 1919).

The success of the students involved in the theater's artistic activities had both positive and negative consequences: on the one hand, M. Mordkin's school was at the peak of popularity, on the other hand, the artist received an additional pedagogical load, for which he was not ready: in the summer of 1919, the Section of Stage Education of the Kyiv City Council obliged Mordkin to work in a free choreographic school for proletarians for 100 people (Visti, 1919).

In the theatrical season 1918-1919 M. Mordkin directed on the stage of the K. Liebknecht Kyiv State Opera House ballets Giselle by A. Adam and La Fille mal gardée (The Wayward 
Daughter) by P. Gertel by the efforts of his studio students (Vasylko, 1984: 150). Thanks to the announcements of theatrical premieres published in the Musical Bulletin No. 1-3 (information for June - July) 1919, we can find out the full cast of the participants in the performance, whom we conditionally call M. Mordkin's studio students. There are Alena, Abramova, Balashova, Bankovskaya, Barbo, Bycheva, Bronskaya, Buchinsky, Virskaya, Vozdvizhenskaya, Volova, Volfovich, Desnitskaya, Zhabchinskaya, Zalevskaya, Zimin, Kamorna, Karitsky, Karnetskiy, Krivtsova, Kudina, Lange, Levenberg, Lugovskaya, Lyadova, Moisen, Muravin, Nelidova, Petrakevich, Polesskaya, Preobrazhenskaya, Ratina, Sabina, Savchenko, Sanovskaya, Svatkovskaya, Svengaevsky, Tarasova, Timan, Fedorova, Flor, Chumicheva, Yakovleva I, Yakovleva II, Yansen among them (Muzykalnyj vestnik, 1919).

Giselle was decorated by A. Petritsky (costumes by artist Grechanin), conducted by M. Steiman and N. Bakaleinikov. The main parts were performed by: M. Froman (Giselle), M. Mordkin (Albrecht), Bankovskaya (mother of Giselle), I. Chistyakov (servant of Albrecht), M. Froman (Elder Duke), B. Pozhitskaya (Bathilde), Ustinsky (Forester) (Dejch, 1988: 7). E. Surits rightly pointed out that the Kyiv production of Giselle in 1918 strongly resembled the performance of 1915, not only in the choreographic, but also in the scenographic key, since A. Petritsky significantly relied on the artistic developments of K. Korovin (at the same time, in contrast to the last one, he chose the concept of excessive historical authenticity) (Surits, 2006: 113). Researcher V. Poklad emphasized that, taking into account the compositional concepts of A. Gorsky, M. Mordkin, at the same time, brought in the performance several his own choreographic decisions: he made separate choreographic cuts (abandoned the variation of the soloists in the second act), strengthened the acting of the main parts performers, increased the number of stage props, implemented a new lighting plan for the performance (Poklad, 2017: 196).

\section{M. Mordkin's creativity in music and drama theaters}

It should be noted that in addition to working at the K. Liebknecht Kyiv State Opera House, M. Mordkin took part in the work of the State Ukrainian Musical Drama, created in June 1919 at the initiative of the directors L. Kurbas and M. Bonch-Tomashevsky. The creative team also included conductor M. Bagrinovsky, singer M. Litvinenko-Volgemut, scenographer A. Bondarchuk, director S. Bondarchuk.

Y. Stanishevsky noted that the ballet troupe, headed by M. Mordkin, numbered forty people (Stanishevskyi, 2003: 39). The first performances of the collective were M. Lysenko's opera Drowned, the ballet (rather, a synthetic performance) Asiada to the music by L. Burgo-Ducudre and I. Gutel, as well as a number of divertissements: Dance with a bow and arrow from the ballet Salammbo by A. Arensky; Bacchanalia by O. Glazunov; Mazurka from the opera Ivan Susanin by M. Glinka; Dreams to music by F. Chopin (Stanishevskyi, 2003: 41).

The Asiada (another title is Arabian Nights) premiered on August 19, 1919. It is known about the ballet that it was first staged by M. Mordkin under the influence of M. Fokine in 1910 for the second American tour with A. Pavlova. This time the choreographer significantly updated the choreographic and musical editions enlisting the support of conductor M. Bagrinovsky, artist A. Petritsky, actor and director L. Kurbas, who played the role (with text) of Sheikh (Bondarchuk, 1969: 93-94).

Subsequently, the same creative team prepared the operas Pebbles by S. Monyushko and Taras Bulba by M. Lysenko (with the participation of L. Sobinov). Moreover, in Pebbles L. Kurbas was to a certain extent artificially Ukrainianized the plot, which told about the events 
from the life of the girl-hutsulka. With the support of V. Verkhovinets, M. Mordkin managed to create original dance pictures on the Hutsul theme, the center of which was the male dance "Arkan". Unfortunately, the premiere of the opera (and with it the show of choreography) did not take place, because on the appointed day (August 30, 1919) the troops of A. Denikin and $\mathrm{S}$. Petlyura entered Kyiv at the same time. Under the shelling, the scenery and musical material of the performance were completely destroyed.

It is important to note that the search of original stage solutions by M. Mordkin did not pass without leaving a trace for the Kyiv creative intellectuals: for example, L. Kurbas in subsequent years widely used the method of working with plastic material developed by M. Mordkin in theater practice. In particular, the theater critic A. Deich, in his memoirs about L. Kurbas's production of Oedipus the King, left the following remark: the chorus was "pantomimic, something like a new ballet in the style of Mordkin ..." (Dejch, 1988: 182).

We will emphasize that in addition to opera and ballet performances M. Mordkin was busy preparing dramatic premieres during his work in Kyiv. So, on May 1, 1919, the production of Fuente ovejuna (Sheep source) based on the work of F. Lope de Vega, consonant with the then revolutionary events, took place on the stage of the Theater of the Ukrainian Soviet Republic named after V. Lenin. The director of the performance was K. Mardzhanov who is known as the commissioner of the theaters of Kyiv. Following the dramatic decision of the last one, M. Mordkin staged the choreographic picture Dance with Cloaks, which, according to E. Surits, became one of the most emotional scenes of the performance. The art critic wrote: "It arose when the rebellious people rejoiced after the victory over the enemy who had fled from the battlefield. In the context of the performance, it was not just a folk dance, but a dance of the winners" (Surits, 2006: 115). The researcher was convinced that thanks to the work on the play of M. Mordkin it became one of the most important artistic events of cultural and political life of the city of that time.

It must be said that the intensification of the political conflict in Ukraine, as well as a significant deterioration of socio-economic conditions of life in Kyiv prompted M. Mordkin to leave the city in October 1919 and go to the Crimea.

\section{Conclusions}

The Kyiv period of M. Mordkin's creativity was closely connected with his activities in the field of ballet pedagogy, choreographer and performance practice. His productions of the ballets Giselle, La Fille mal gardée (The Wayward Daughter), Asiada, as well as dance numbers and divertissements in opera and drama performances became significant for the artistic life of the city. M. Mordkin gained valuable director experience from the cooperation with representatives of the Ukrainian creative intellectuals (L. Kurbas, M Bonch-Tomashevsky, A. Petritsky, V. Verkhovinets). The stage skills of Mordkin as the dancer served as an example for inheritance for many Ukrainian ballet dancers. Mordkin as the teacher managed to significantly increase the size of the ballet troupe of the Kyiv Opera in a short time. It was made thanks students from his own studio, he expanded their professional capabilities through careful and systematic physical training.

We consider that the study of the creative biographies of the artists of the M. Mordkin's dance studio, a detailed understanding of the influence of M. Mordkin on the creative plastic method of L. Kurbas, the restoration of the main milestones of M. Mordkin's activity in the Crimea after leaving Kyiv, etc. are prospective and possible directions for further research. 


\section{References}

Bilash, O. (2019). Balet «Marna perestoroha»v istorii ukrainskoho baletnoho teatru [Ballet "Vain Caution" in the history of Ukrainian ballet theater]. Kultura i suchasnist, № 2, 75-79. [in Ukrainian].

Bondarchuk, S. (1969). Molodist Kurbasa [Kurbas's youth]. V. Vasylko (Eds.). Les Kurbas: Spohady suchasnykiv [Les Kurbas: Memoirs of contemporaries]. Kyiv: Mystetstvo, 88-94. [in Ukrainian].

Chechel, N. (1993). Ukrainske teatralne vidrodzhennia: Zakhidna klasyka na ukrainskii stseni 1920-1930-kh rokiv. Problemy trahediinoi vystavy [Ukrainian theatrical revival: Western classics on the Ukrainian stage of the 1920s and 1930s. Problems of tragic performance]. Kyiv. [in Ukrainian].

Dejch, A. (1988). Chelovek, kotoryj byl Teatrom [The man who was the Theater]. M. Labinskij, L. Tanyuk (Eds.). Les Kurbas: stati $i$ vospominaniya o L. Kurbase. Literaturnoe nasledie [Les Kurbas: articles and memoirs about L. Kurbas. Literary heritage]. Moscow: Iskusstvo, 173-191. [in Russian].

Muzykalnyj vestnik. 1919, № 1-3, 7-10. [in Russian].

Poklad, V. (2017). Do istorii stvorennia baletu «Zhizel» na stseni Kyivskoho natsionalnoho akademichnoho teatru opery ta baletu im. T. Shevchenka [To the history of the creation of the ballet "Giselle" on the stage of the Kyiv National Academic Opera and Ballet Theater named after T. Shevchenko]. Naukovi zapysky. Seriia : pedahohika, issue 136, 192-200. [in Ukrainian].

Stalinskij, O. (1994). Iz vospominanij ochevidca kievskih gastrolej Ajsedory Dunkan [From the memoirs of an eyewitness to the Kiev tours Isadora Duncan]. Ajsedora Dunkan [Isadora Duncan]. Kyiv: Muza LTD, 337-344. [in Russian].

Stanishevskyi, Yu. (2002). Natsionalnyi akademichnyi teatr opery ta baletu Ukrainy imeni Tarasa Shevchenka: istoriia i suchasnist [Taras Shevchenko National Academic Opera and Ballet Theater of Ukraine: History and Modernity]. Kyiv: Muzychna Ukraina. [in Ukrainian]. Stanishevskyi, Yu. (2003) Baletnyi teatr Ukrainy: 225 rokiv istorii [Ballet Theater of Ukraine: 225 years of history]. Kyiv: Muzychna Ukraina. [in Ukrainian].

Suric, E. (2006). Artist baleta Mihail Mihajlovich Mordkin [Ballet dancer Mikhail Mikhailovich Mordkin]. Moscow : KomKniga. [in Russian].

Teatral. 1919, April 9-10, 2. [in Russian].

Vasylko, V. (1984). Teatru viddane zhyttia [A life devoted to the theater]. Kyiv : Mystetstvo. [in Ukrainian].

Visti. 1919, June 22, 3. [in Ukrainian]. 